\title{
SOCIOLINGUISTICS AND LINGUISTIC GEOGRAPHY
}

\author{
RAVEN I. MCDAVID, JR. \\ University of Chicago \\ RAYMOND K. O'CAIN \\ University of South Carolina
}

\begin{abstract}
Sociolinguistics and linguistic geography should be considered as complementary rather than mutually contradictory approaches to the phenomena of language variation. Linguistic geography is a branch of historical linguistics based on samples of the stable and traditional, and necessarily somewhat biased in the selection of small communities, older informants, and traditional cultures; however, it provides a framework for interpreting studies of varied populations-in both rural and urban communities. The authors review criticisms of both linguistic geography and of sociolinguistics applications of linguistic geography, and suggest directions in which the findings of linguistic geography may be useful to sociolinguists and others in matters of interdisciplinary cooperation.
\end{abstract}

\section{Introduction}

Disagreements among scholars are inevitable as each emphasizes his interests. Yet it should be possible to maintain a level of intellectual discussion even though there may be differences in interpretation. Though Leonard Bloomfield and Edgar Sturtevant never agreed on the nature of sound change-one emphasizing minute variations, the other emphasizing lapses-each was careful to see that the other's point of view was presented to his students, and for more than a quarter century they were warm personal friends. It should be even easier for those who are looking at different kinds of evidence, for different purposes, to recognize that their fundamental aims are not necessarily in conflict, but that each may enlighten the other. And if the differences in perspective have led to misunderstanding, it is the part of rationality to explain the basis of the disagreement, in the hope of rapprochement.

Such a situation has arisen in connection with the work of the linguistic geographers and the sociolinguists. Both deal with variations in usage within a speech community; though their methods and their populations are somewhat different, each should be able to illumine the other. Yet somehow there has developed the notion that the two groups are irreconcilable adversaries.

It is the hope of this paper to indicate the origins of recent disagreements, to discuss some of the criticisms that have been made on each side, to answer or explain such criticisms, and to suggest directions which might lead to greater 
cooperation. Human language, specifically English spoken in the continental United States and adjacent territory, is so complicated that it would be foolish to suggest that any one person or school has all the answers.

The authors believe that their experiences provide insights. Both have had considerable field work in traditional linguistic geography; both have engaged in (and directed) research in social dialects. Both have had from their fathers practical training in sociology-one being an industrial lobbyist, the other a small town doctor. One (R.I.M.) grew up in the inner city of an industrialized metropolitan area, the other in the seat of an agricultural county with a Negro majority and two Negro colleges. Both have grown up in the South but have spent considerable portions of their professional careers in the North; and since both married Middle Westerners, they have had to face the problem of cross-regional communication on an intimate level every day. Perhaps these experiences will produce objectivity toward matters that have too often evoked passion; perhaps this study will constitute a small step toward an understanding between the practitioners of two aspects of our discipline that should never have been placed in opposition.

\section{The Rise of Applied Sociolinguistics}

Here, as often, we need historical perspective. For at least two millenia, it has been recognized that some of the kinds of language variation within a speech community are socially significant; the development of monolingual dictionaries, manuals of pronunciation, and grammars of the native language is indicative of that recognition, and the curriculum of the public schools has been built around the teaching of what have been considered the standard varieties of the language. But in only a handful of American communities has the language been studied in any detail, because the attention of linguists has been concentrated on such matters as the teaching of second languages (especially exotic ones), the teaching of English to speakers of other languages, and the theoretical issues arising from concerns with language universals, an interest in symbolic logic, and attempts to provide systems of machine translation.

All of these serious concerns of linguists have been mission-oriented; sociolinguistics proved no different. It was directed to problems of the poor in large metropolitan areas, and to the apparent failure of the schools to fulfill their traditional role as an instrument of acculturation for such groups as Southern-reared blacks and Spanish speakers from Puerto Rico and the American Southwest. The American public was aware of the problems of these groups and of the language differences that seemed related to these problems if not their actual cause. Many of these investigations, it turned out, lacked a grounding in English historical linguistics because they were initiated by scholars from other disciplines. This was probably inevitable since departments of English have shown an increasing disposition to become merely departments of English literature and to abandon the study of language.

Most of the new investigations took place in large metropolitan areas, complex in economic and social organization. Involved in the language of blacks and Spanish speakers, but overlooking great numbers of native white disadvantaged, they were often inaugurated under the auspices of school boards or social service institutions and focused on adolescent peer groups. 
Perhaps no other circumstances would have directed so much attention on the speech of urban blacks, or have produced so much useful evidence. But there have been relatively few follow-up studies putting the evidence from these investigations into the perspective of the fifteen-century history of the English langauge. Students of historical linguistics frequently ask whether supposedly divergent features of, say, urban black speech are such special cases, since similar features are well attested in the regional varieties of Middle English.

Among the special concerns of recent sociolinguists have been the possible affiliations of the speech of blacks with various pidgin and creolized languages-varieties of English, French, Portuguese, and the like-known or suspected to have been spoken in Africa, the Mediterranean, and the West Indies. This interest, again, is desirable, as suggesting new complexities in the already recognizably complex history of English. But again, the creolists have examined only part of the evidence. Few of them have matched their awareness of Sabir, the lingua franca of the Mediterranean, with a familiarity with Joseph Wright's English Dialect Dictionary (1898-1905); many of them insist that alternative and probably reinforcing origins of words and structures in the speech of American blacks must be the necessary and only origins.

\section{Evaluation of Sociolinguistics by Linguistic Geographers}

Inevitably, the conclusions of sociolinguists have been reviewed by linguistic geographers. The latter have always been concerned with the problems of language variety in speech communities and on the American scene have added a social dimension to their traditional concern with regional differences. Even though linguistic geography has never been a very popular or well financed branch of American linguistics-unlike the situation in many European nations-there have been four decades of systematic investigations and many publications, both primary and derivative (e.g., Kurath, et al., 1939, 1939-1943; Kurath, 1949; Kurath-Lowman, 1970; Kurath-McDavid, 1961; Atwood, 1953, 1962; Allen, 1973-) that might be taken into account by sociolinguists in evaluating varieties of American English and its potential origins in the British Isles. But this evidence-to say nothing of the unpublished materials in the archives which have always been open to scholars-have rarely been used in American sociolinguistics. ' Only Labov (1963, 1966, 1972) has made serious use of what linguistic geographers have done, and in his 1966 study he used only secondary summaries (Frank, 1948; Kurath-McDavid, 1961). Dillard (1972), a popular argument for the creolist position, mentions linguistic geography largely to misrepresent it (D'Eloia, 1973), and his index does not list Kurath, the founder of American linguistic geography.

There is no necessary argument between creolists and linguistic geographers. Linguistic geography is not a theory but a method of inquiry, a method that can be used to support a wide range of general theories and particular arguments. Where the evidence demonstrates that features of American English-or of some of its varieties-can be traced to other languages, whether French or Spanish or German or West African, linguistic geographers are prompt to recognize the facts (Davis-McDavid, 1949; McDavid, 1950); but where alternative explanations seem possible, in the light of information about British dialects or of English elsewhere in the New World, where foreign-language influence is improbable, they urge caution. Marckwardt (1948) demonstrates that want off for want to get off is probably not of Pennsylvania Dutch origin; the incontestable fact that Southern tote ("carry on the person") is influenced by a West African etymon does not exclude the 
possibility of reinforcement from another source, since tote ("transport in a vehicle") is widely found in Northern lumbering country from Maine to Minnesota. Nor is it likely that Dalby (1971) offers more than another case of homonymy in different languages when he points to a West African affirmation that sounds like $O . K$.; the basic case has been carefully put in Read $(1963 a, b)$.

What the linguistic geographer expects of the sociolinguist is some attention to previous research. For instance, if there should ever be an intensive study of the speech of Asheville, North Carolina, it is reasonable to expect the investigators to examine field records for the Linguistic Atlas of the Middle and South Atlantic States, as well as earlier studies of the speech of Western North Carolina. Preliminary work would make possible a more effective questionnaire directed to features known or suspected to be socially significant in the community, without freezing the design. The sociolinguist should also ascertain whether these features also occur in areas from which the people of Asheville have come. The need to examine the record is a familiar experience for the linguistic geographer, who must still contend with the mythology that in certain coves of eastern Kentucky the natives still speak "pure Anglo-Saxon"-something, by the way, that was on the wane in England before the Normans crossed the Channel in 1066.

\section{Criticism of Linguistic Geography by Sociologists}

Sociological criticisms of the methods of American linguistic geography stem from Pickford (1956). Since her remarks have frequently affected the attitudes of sociolinguists (cf. Wolfram, 1969, for example), it is well to discuss them in some detail (see also L. M. Davis, 1967, 1970). In brief, Pickford's view was that the Linguistic Atlas, essentially a continuation of traditional European linguistic geography, had sampled the most isolated and conservative elements of a highly urbanized and mobile society, and the research instrument was appraised as one that would exaggerate localisms.

Though citing Dieth (1948), Pickford apparently did not understand that most Europeans have traditionally made a sharp distinction between "the language" of the urban elite of influential cultural centers like London, Paris, or Florence, and the "dialects" that differ along social or geographical dimensions. Thus Dieth rebuked Americans for an "alarmingly modern" (1948: 76) questionnaire that sought variants of words like umbrella, baby carriage, and sidewalk which he did not consider "dialect" words at all. Dieth was "perplexed" (1948: 79) that words with interesting variants in British English, like left-handed, tangle of hair, and loose piece of skin at the root of a nail, were not included. Dieth felt, in fact, that Americans had unjustifiably included phonological and grammatical variants at the expense of a full treatment of the regional vocabulary. Dieth also faulted Kurath, et al., (1939-43) for maps showing variants with predominantly social rather than regional distribution. While conceding that the study of social variation might be inherently interesting, Dieth insisted that it had no place in dialect geography. Pickford apparently chose to ignore these criticisms; most influential on American linguistic geography was Jaberg and Jud (1928-40), the least traditional European atlas, as is clear from Pop (1950).

Pickford focuses on the homogenizing forces in American society and consequently regards regional identification as relatively insignificant in an urbanized and mobile society. ${ }^{2}$ Hubbell (1950) is cited to support the contention that local identity, if it exists in New York City, has no linguistic reflection, for New York is not characterized by purely geographical 
distribution of speechways. ${ }^{3}$ And to Pickford, the cities appear to be quite uncharacteristic of the dialect areas into which they should fall if purely geographical considerations were important.

Cities, in fact, are characteristically composed of significant proportions of persons native to other places. ${ }^{4}$ Newcomers often form cultural outposts of their homes. Urban cultures are a composite of their components; in London of the 1400's, there were competing forms of the masculine and feminine for fox: London fox and fixen, Southern vox and vixen. Fox and vixen became established in London standard English while the other forms fell out of favored use.

Pickford overlooks an important remark by Hubbell: "An observer . . . with a sufficient knowledge of the metropolitan dialects, could make very shrewd guesses about the family background of the various speakers, the kind of neighborhoods they grew up in, and so forth" (1950: 11). Not only does this support Pickford's point that various complexes of group cross-affiliation assume increased importance in an urbanizing society, but it also harmonizes with the findings of linguistic geographers (e.g., Kurath, et al., 1939-43): cities have fewer linguistic variants, but the variants often indicate social stratification; rural areas have more variants, but the variants are less likely to have social significance. Cities are not atypical of the geographical areas in which they lie, but are cultural foci from which the urban linguistic consensus-a complex of blended regional characteristics and urban innovations-radiates. And a linguistic feature may oscillate between status as a regional trait and a social trait, as McDavid (1948) and O'Cain (1972) have shown for $r$ in words like car and cara.

The speech of American cities (or even of cultivated persons) is far from uniform or lacking in regional associations. No supraregional term exists, for example, for the grass between the sidewalk and the street, known variously as the boulevard in Minneapolis or the parkway in Chicago. In New Orleans, one orders a poor boy sandwich, but a hoagy in Philadelphia, a hero in New York City, a grinder in upstate New York, a submarine in Boston. All of these have been widely disseminated as commercial terms. Sometimes urban speechways skip from city to city, leaving the intervening territory to be filled in by radiation from nearby cultural centers. The Chicago term clout for political influence has recently attained national status, but the dispenser of political favors is known as a chinaman only in Chicago (McDavid, 1969). 5

Also derivative from Pickford are the criticisms of the Atlas method of determining the social class of informants. A common misconception is that the field workers for the Linguistic At/as used education alone as an indicator of social rank. This seems to have originated in the widely quoted summary of social types from Kurath, et al., (1939):

Type I: Little formal education, little reading and restricted social contacts.

Type 1I: Better formal educaton (usually high school) and/or wider reading and social contacts.

Type III: Superior education (usually college), cultured background, wide reading and/or extensive social contacts (Kurath, et al., 1939: 44).

Presumably the conclusion that the Linguistic Atlas assumed the existence of just three social classes also proceeds from Kurath's summary. Generally ignored and seldom quoted is Kurath's caveat:

For any treatment of social differences in speech and for any attempt to determine trends of change, the lives of the informants (Chapter VI) must be consulted. For ready reference, the accompanying rough tabulation of all informants by types should prove serviceable (Kurath, et al., 1939: 44). 
Linguistic geographers are aware that no single characteristic is an adequate indicator of social class. ${ }^{6}$ They have always assumed that each community would have its own social structure, just as each works out its own linguistic consensus. They also know that communities differ in the relative size of the classes, in the relative significance of specific social characteristics, and in the sharpness of social boundaries.

A social profile was assembled for each informant by an occupational, educational, and social history: organizational memberships, church affiliation, reading habits and intellectual interests, travel, and the like. Similar information was sought for the informant's parents, grandparents, and spouse. ${ }^{7}$ Field workers also paid close attention to the views of both informants and other residents of the communities regarding the social structure and the places of individuals within it. ${ }^{8}$ In addition, there was considerable incidental observation in the course of four to twenty hours of personal contact in the homes of informants. There was also sociological content in portions of the linguistic interview, as in the descriptions of the house and its furnishings, and names for social types like rustics, poor whites, and Negroes. Finally, all these observations were considered in the context of an historical perspective-with which field workers were expected to familiarize themselves in advance-on the class and ethnic composition, economic life, and relationships of the communities to surrounding places. ${ }^{9}$

In short, it was not the aim of the Linguistic Atlas to break ground in the theory of social stratification but to record the usage of unequivocal social types in relatively stable communities in order to reconstruct as nearly as possible the regional patterns of American speech of a slightly earlier time and to provide a context for the study of intermediate types of communities and social levels. Linguistic geographers admit that they have not explained in detail how the information bearing on social rank was correlated nor how important they regard each type of information. ${ }^{10}$ Nevertheless their practice is in accord with the summary statement of Brown:

The reality of class in a community will be undeniable in the following circumstances: (1) the population is conscious of classes, agreed on the number of classes, and on the membership of them; (2) styles of life are strikingly uniform within a stratum and there are clear contrasts between strata; (3) interaction is sharply patterned by stratum; (4) the boundaries suggested by the three kinds of data are coincident (1965: 114).

\section{The Aims of Linguistic Geography}

It is important to explain (particularly for readers from other disciplines) the background of American linguistic geography. It appears that some critics fault American linguistic geographers for not doing what the latter never attempted to do and indeed never could do.

Although interest in dialect differences is old, modern linguistic geography is in origin a branch of historical linguistics. ${ }^{11}$ It arose out of the desire to test some of the general assumptions of comparative linguistics, notably the theory of the regularity of sound change-the notion that statements of sound change admit of no exceptions. This theory had arisen in Germany, and in Germany it was first put to the test. Assuming that there was a sharp boundary between the Low-German (North-German) area, where one would encounter make(n), ik, and pund (English make, l, and pound), and the High-German (South-German) area, where one would encounter machen, ich, and pfund, Georg Wenker prepared a questionnaire that in its 
final version consisted of forty-four standard German sentences, and asked village schoolmasters to put these sentences into the local dialect. Ultimately, information was collected on more than forty thousand village dialects, and edited to form Wrede (1926-39). The result was a general confirmation of the belief in clearly defined dialect areas, but with two exceptions: (1) for no two words did the lines between Low-German and High-German forms coincide exactly; (2) in certain regions-notably the Rhineland-the lines even tended to spread some distance apart. ${ }^{12}$ These divergences from the expected norm of a sharp dialect boundary were ultimately explained after more intensive regional studies and the examination of historical evidence of political boundaries, trading areas, and the like. But the German dialect evidence was all taken from village speech; standard High-German was assumed as the norm against which the local dialects should be measured, and influence of cities could be judged only inferentially.

L'Atlas linguistique de la France (Gilliéron, 1902-10) originated in a different theoretical atmosphere, but again it sought to test assumptions of a sharp boundary, this time between French proper and Provencal, as well as such matters as the disappearance of homonyms. The evidence was gathered by a single trained investigator (Edmond Edmont) instead of by correspondence; some six hundred villages were selected for investigation, with one typical speaker of the local dialect interviewed in each; the questionnaire was considerably longer than that used by Wenker; Edmont recorded the responses in a finely graded phonetic transcription. Most of Gilliéron's principles are still accepted by linguistic geographers, though certain technical aids have modified their application: the tape recorder makes it possible for the investigator to reexamine his transcription in a way denied Edmont. Despite the difference of his methods from those of Wenker, Gilliéron worked from the same basic assumptions: his evidence was all derived from village speech, assumed as sharply contrasting with standard French, and even the influence of Paris can be determined only inferentially, in terms of what happens in the villages. ${ }^{13}$

The investigation of Italy (Jaberg and Jud, 1928-40) introduced other modifications. Cities were investigated as well as villages; in a number of the larger cities there were two or more interviews. Perhaps even more important was the ethnographic interest of the investigation and its emphasis on language as a part of human behavior; the words for plow were sought in terms of the use of the tool, and the pronunciations again were indicated in finely graded phonetics. That Jud and his principal field investigator, Paul Scheuermeier, participated in the training of the first group of American field workers illustrates the continuity of the discipline.

When plans for a survey of regional speech in the United States and Canada were drawn up in 1929-30, some scholars wished a survey on the older European model-a concentration on rural speech with a single, minimally literate person interviewed in each designated community. But there were several stronger counterarguments: (1) American society has had a strong urban component from the beginning (Bridenbaugh, 1938); (2) by 1930 more than half the population of the United States was living in urban communities; (3) unlike the situation in Germany or France or Italy, where there was a more or less uniform standard variety of the language against which local folk dialects could be measured, there were strongly defined regional and even local varieties of educated speech, which themselves were subject to change under the centripetal forces that tended to dominate American society-notably geographic and social mobility, urbanization, industrialization, and the commitment to general education (McDavid, 1970). It was therefore decided to seek three types of local speakers instead of one: (1) as in previous investigations, in every community, someone old and minimally educated; (2) likewise in every 
community, someone a bit younger and with a moderate amount of education; (3) in about a fifth of the communities, someone representing the local traditions in cultivated speech, as attested by family background, education, and general intellectual interests. This last type was interviewed less often because the speech of the highly educated differs less from place to place than that of other groups; but in general, the investigators included a representative of this group from every important cultural center, past and present.

All of the persons interviewed were expected to be natives, and the longer the family had been resident in the community the better, other things being equal. This is far from a random sampling of the population, but since the purpose of the American surveys was to provide benchmarks in the historical study of the language both for comparison with British dialects, past and present, and for suggesting the direction of linguistic change-it was necessary, as in all linguistic geography, to work with people strongly identified with their communities, however unrepresentative they may have been from a purely statistical viewpoint. Especially necessary was the statistically disproportionate emphasis on the speech of the old and minimally literate (and often the cultivated speakers, too, were drawn from the older generation), since their speechways reached further back in time and provided richer comparative evidence. For the same reason, most of the communities (though far from all) were small towns, villages, or rural neighborhoods, where metropolitan fashions would have had the least effect. For the same reason, the questionnaire tended to emphasize the traditional, rural and domestic parts of the vocabulary, since these were the items where previous studies had already indicated the greatest amount of regional and social variation. By the standard of European dialectology, though, the New England questionnaire and its successors were rather unorthodox, including as they did for vocabulary variation such items as kerosene and Civil War, and for pronunciation, such institutions as library, post office, and hotel. These items were included for the same reason as the others-that in some way they appeared to pattern with other markers of regional and social differences in English-speaking North America. By including cities as well as villages, cultivated speakers as well as the uneducated, innovations as well as relics, the American linguistic atlases differ sharply from their predecessors in providing evidence on social differences and the dimension of time, even though still insisting on speakers closely identified with their communities.

The regional atlases do not provide a full sociolinguistic description of the speech of the United States, or indeed of any community, large or small. They do not attempt to sample the usage of transients or recent arrivals; and they provide only a rudimentary sketch of the class system. Probably few American communities have exactly three social classes; the investigators for the more sophisticated community studies, like Warner and his associates, work with six or seven; others consider the question moot, insisting that one can never predict in advance the number of social classes in a community yet uninvestigated, but must depend on the investigation to reveal just how the inhabitants judge each other's status. What the atlases do is to provide a framework for more intensive investigations and certain indications of social differences against which the findings of a later date may be assessed. If sometimes the direction of change, or the influence of an older cultural center, is not sustained but even apparently reverses itself (Bailey, 1973), it must be remembered that the language behavior of an individual or of a group is the resultant of a multidimensional polyhedron of forces-family background, childhood neighbors, education, travel, occupation, etc.-and that new forces, or new intensities of older ones, may alter the direction of the resultant. That often the evidence of a regional atlas or an analogous study suggests this new direction is fortuitous and 
cannot be assumed in every instance. If even the ideal questionnaire cannot be devised until the field investigation is completed, it is safe to say that a regional survey that could infallibly predict the course of change in a given community can be designed only at the end of human history.

Conceding the limitations of the coverage of the communities that have been investigated, we may as freely admit that many communities or social groups may not have been investigated at all, and that others may have been investigated less than they deserve. Again, the regional atlases simply provide a framework against which the findings of new investigations may be interpreted, and perhaps suggest the reasons for apparent discrepancies.

\section{From Linguistic Geography to Sociolinguistics}

Linguistic geography thus grew out of the interest in historical linguistics that had developed in the early part of the nineteenth century. It arose in response to questions about the assumptions of comparative linguistics, notably the regularity of sound change and the sharpness of dialect boundaries. The evidence it provided caused a reexamination of earlier theories and a search for explanations; it also indicated-even when only village speech of one social level was investigated-a number of fruitful suggestions about the dynamics of speech communities and the origins and directions of linguistic change.

In the same way, sociolinguistics is bound to challenge some of the findings of linguistic geography. Regional surveys-French, German, or American-leave unanswered several questions with which sociologists (not to mention educational administrators) are most highly concerned: the usage of all the community, not just that of the longestablished native population; the assimilation of speakers of other languages and of minority groups within the language community; the language of the younger generations; and, particularly, the statistical frequency of competing usages. Frankly, the regional surveys have not dealt with all the groups in the communities they have covered, and the techniques of investigation, with the traditional long questionnaires, do not lend themselves to quantification. V. McDavid (1956) points out that in several communities of the North-Central States, one finds four preterite forms for the verb to see-saw, see, see, seen-sometimes in the usage of a single informant. But there is no way to determine which of these is most common for the community, or even for the informant, or more likely to prevail in certain styles of discourse. New types of research instruments were needed, such as those in Labov (1966) and Shuy, Wolfram, and Riley (1968); and the use of the tape recorder permits the tabulation of every occurrence of a linguistic form (whether a word or a particular pronunciation of a vowel or consonant).

With new research designs developing and new technology available, an ideal model for the development of sociolinguistics might follow the progression sketched in Kurath (1968). First, one would investigate relatively small and stable communities, well within the limits of dialect areas, and with a long English-speaking tradition. Then there would be a progression of complexity, involving an assortment of variables: somewhat larger communities, communities located on or near the boundaries of dialect areas, communities that had undergone rapid expansion of population, communities with groups of speakers of languages other than English. As the complexities grew-first with one variable added, then with two (in various combinations), then more-the methods would undergo repeated testing until the largest and most complex 
metropolitan areas were investigated. This would parallel the progression in the development of community studies, by the Lynds (1929, 1937), Withers (1945), Dollard (1937), Davis and the Gardners (1941), the Warner group (1941, 1942, 1949), and others.

However, such an orderly progression was impossible. The sense of urgency and the accessibility of funds were both far greater for Detroit and New York than for Vermontville, Michigan, or Social Circle, Georgia. Research is undertaken, inevitably, where funds are available and people are available to undertake it. Consequently, investigations were launched in Detroit and Washington and New York before the techniques had been tested in smaller places. And even when smaller communities were studied, such as Hillsboro, North Carolina (Levine and Crockett, 1966), which was accessible to the state university at Chapel Hill, they were not necessarily the simpler type that Kurath had envisaged; Hillsboro is on the margin of four distinct dialect areas: the Virginia Piedmont, Western North Carolina, the Pee Dee-Cape Fear Valleys, and Northeastern North Carolina (Kurath, 1949, Figure 3). The emphasis on complicated communities was inevitable under the circumstances. Nevertheless, the experience of linguistic geographers would suggest certain safeguards:

1. The information about the regional framework could be utilized insofar as it is available, especially if there are records from the community itself. ${ }^{14}$ Field records indicate something of the linguistic differences and similarities in the native population at the time they were made. They suggest the particular linguistic features-whether in grammar, pronunciation, or vocabulary-that might be studied more intensively, so that the interviewers' instrument could be maximally productive. The homonymy of ear and air (and their congeners) is likely to be a significant item only in a community where some of the population have had it.

2. In the same way, the investigators could make use of information about the speech of the region from which large groups of migrants have come, English-speaking or otherwise. If any speakers come from regions that have homonymy of pen and pin, for example, this feature could be investigated in the host community.

3. The class structure of the community should be approached in terms of the community evaluation. There should be an effort to supplement economic criteria of class structure ${ }^{15}$ with other ones; the affluence of skilled and semi-skilled labor-in many communities truck drivers and garbagemen have larger incomes than university professors and live in larger and more modern homes-brings us back to the truism that as the overt class markers are blurred, the covert ones become more important. Even within the same profession one must be cautious: a municipally supported junior college may have a higher salary scale than a prestigious private university in the same community. Despite all the pressures towards uniformity, American communities remain refreshingly different; the social structure of each must be studied in its own right, and extrapolation kept to a minimum, with regard both to the number of classes and the linguistic markers associated with each.

Inevitably the sociolinguist must develop his own techniques and instruments, regardless of what has been done before. And no one should be surprised if, with the plentiful evidence recorded interviews provide, he uncovers unsuspected markers of caste and class. This should be no more surprising than that new and unsuspected markers turn up all the time in the experience of linguistic geographers; the alternation between slick and slippery to describe a blacktop road after a light rain is apparently another marker of the difference between the North and the Midland, since in Michigan slick is associated with 
Indianians and in New York with Pennsylvanians. But such newly discovered markers are likely to be more significant if the investigator has a way of correlating them with those already known or suspected to exist. Slippery and slick parallel the North/Midland contrasts between dove and dived, cherry pit and cherry seed, and an and ' $n$. The nature of science is cumulative; like others, sociolinguists build on what has previously been learned.

\section{Applications of Linguistic Geography}

The Atlas framework has provided a solid basis for further research. By sampling the usage of clearly defined baseline social and regional types it is possible to predict with some success the direction of linguistic change. McDavid (1948) predicted that preconsonantal and final $r$ in words like card and car would be restored in $r$-less Charleston, South Carolina, as a result of social changes then in progress. O'Cain (1972) confirmed McDavid's prediction on the basis of an intensive secondary investigation about a generation later. The $r$-less pronunciation of Charleston changed first from a social to a regional marker, and now, in a reversal of social values, is becoming a social marker again. This sort of direct observation can never be replaced by the study of texts, for in the three hundred years in which English has been spoken in South Carolina, the spelling system has not reflected changes in the pronunciation as it did in the preceeding three centuries.

Of course, the direction of sound changes cannot be predicted infallibly; Labov (1963) found that the expected developments in the pronunciation of the vowels of words like right and route had been arrested and even reversed by certain members of the younger generation on Martha's Vineyard. Island-oriented youngsters cultivated the presumably declining pattern of pronunciation to affirm their identification with the island in the face of social changes in progress. Mainland-oriented youngsters, on the other hand, consistently shifted to less local norms of pronunciation. Labov (1972) has also examined the way social identity on Martha's Vineyard is related to the replacement of distinctive local vocabulary items-first studied systematically for the Linguistic Atlas of New England. ${ }^{16}$

Linguistic geography can also be useful in historical studies of greater chronological span. Kökeritz (1953) would have been a more forceful interpretation of Shakespearean phonology if he had known that words like ear, here, and beer are pronounced like air, hair, and bear or bare in the Low Country of South Carolina (McDavid, 1958).

The largest follow-up study building on the results and methodology of the American linguistic Atlases is the Dictionary of American Regional English, (Cassidy, in progress). D.A.R.E. uses the methods of linguistic geography, with certain modifications, to study regionally distributed words in the United States. The network of communities reflects urban-rural population ratio of the states, but older states are proportionately sampled more heavily than more recently settled ones. The same range of social types as the Linguistic Atlas was interviewed, with the questionnaire sometimes divided among several persons to assure more or less "expert" coverage of various semantic domains. The questionnaire-1002 were completed in nearly as many communities-includes most of the interesting variants uncovered by the regional Atlases as well as a number of other items known or suspected to have interesting regional variants. It reflects changes in life styles: in 
transportation, from hoover cart to jalopy to trailer truck, from back roads to blacktop to interstate. Cassidy also includes evidence from localized written sources of various types-diaries, newspapers, and works of fiction, past and present.

D.A.R.E. uses the questionnaire as a central core to work out in the direction, but not in the expectation, of exhausting the store of localized terms in each community or region. The field worker was expected not only to cover the core materials, but to ask follow-up questions and to keep his eyes and ears open for further localisms.

D.A.R.E. has recorded the changing vocabulary of a changing society. Not many people make their own shingles nowadays, so few know that the tool for riving them out is a frow; likewise, indoor plumbing has deprived us of many local terms for privy. But its field workers also uncover previously unrecorded local terms such as verbs designating "give someone a ride on a bicycle," tow in Charleston, pull in Orangeburg, and double-head in Columbia (all in South Carolina). Likewise, D.A.R.E. is documenting the transfer of old terms to new artifacts, as eye from the wood stove to the electric or gas stove, despite the appliance salesman's use of element, burner, or unit. And icebox is still actively used for refrigerator, as is the early brand name frigidaire. ${ }^{17}$ D.A.R.E. will not comfort those who believe our language is homogenizing.

Last but not least, familiarity with the work of linguistic geographers would also provide insights to those wishing to understand the relationship between the speech of white and Negro Americans. It is a fact that most of the linguistic features that appear to characterize inner-city Negroes are shared not only by many whites of comparable socioeconomic standing, but also by cultivated speakers in the South, especially in casual speech. It would have been a relatively simple matter to look at Kurath, et al., (1939-43) concerning such matters as multiple negation (e.g., Map 718), or at Atwood (1953) and V. McDavid (1956) for verb forms before concluding that certain forms are used exclusively by Negroes. ${ }^{18}$ And Pederson (1972), a sensitive type of "double dialect geography" (Reed, 1961), shows how apparent racial differences in the speech of given communities results from migrations in opposite directions.

\section{New Directions}

One of the most promising ways in which linguistic geographers and sociologists might cooperate is in the design of community studies. Although sociologists disguise the names of the communities on which they report, it is apparent from the descriptions and from critical appraisals that linguistic data might have been illuminated the interplay between regional cultures, as in Withers (1945) and Gallaher (1961), caste and class differentiation, as in Dollard (1937), Davis and the Gardners (1941), or Warner (1941, 1942, 1949).

The uncontroversial nature of dialect data-the only ethical consideration is the anonymity of the informant-makes it a useful instrument for examining social structure. With linguists participating in the planning and preliminary research for community studies, exploratory interviews building on the experience of linguistic geographers could develop a short checklist of locally significant sociolinguistic variables that could be incorporated into tape recorded interviews by nonlinguists for analysis by linguists. But as long as people are talking, no matter what they say, they are providing data for the linguist. ${ }^{19}$ Secondary analysis of sociological interviews might not only turn up linguistic data of interest, but might help interviewers in each field synthesize the strengths of both. 
Although our interests and beliefs may direct us into one field of inquiry or another, they must not hinder our understanding of things as they are. As linguists, for example, we learn early that our own dialects influence the way we hear others. Perhaps the idea that America is becoming homogeneous is a bit of folklore, particularly with regard to the matter of speechways. ${ }^{20}$ The persons who make such observations are those least likely to have very different dialects-the highly educated, mobile, and urban. The speech of those they hear most often has probably been subject to those influences linguistic geographers know to be least favorable to diversity.

Other sorts of common beliefs may have a sociolinguistic basis. The Southerner signals to interlocutors that they are in a casual situation by stylistic shifts to non-literary speech forms, such as the use of ain't or multiple negatives. Thus he is justifiably apt to characterize one who does not show a similar pattern of grammatical and phonological shifts as withholding intimacy. It is little wonder that Southerners find Midwesterners cold, stiff, overly formal, or even hostile. ${ }^{21}$

The complexity and diversity of modes of social interaction in America demand that we be on our best behavior as social scientists and assume that every group works out its own solutions to the recurrent problems of life and that its judgments are not subject to the standards of others. ${ }^{22}$ In this all investigators can agree, however much their methods may differ.

\section{Footnotes}

${ }^{1}$ McDavid (1967) suggests how it might be used.

${ }^{2}$ Diversity may be in the ear of the beholder. The New England maps (Kurath, et al., 1939-43) appeared to Pickford to exaggerate the localisms of the region; Dieth (1948: 66), on the other hand, judges, " . . . we should, by European standards, have expected greater variety." The same lesson obtains in other spheres: Key (1949) charts the diversity and complexity of political behavior in the "Solid South." And lest Key be dismissed as dated in 1973, it should be pointed out that the two key figures in state politics in South Carolina, Senator Edgar A. Brown and Representative Solomon Blatt, who were in their full political maturity in 1949, have shaped the state's politics for years to come. Though Brown retired in 1972 and Blatt relinquished the Speakership of the House of Representatives (a post he held longer than any other person in American history) in 1973, new trends in South Carolina politics are likely to be variations of rather than departures from their statecraft. The persistence of tradition should not be underestimated: George Wallace fully understands the political significance of marriage into the Folsom family of Alabama, just as David Eisenhower understands the political significance of his relatives.

${ }^{3}$ As Americans frequently observe about other matters, New York is not a typical city. Pederson (1965a) points out striking linguistic differences between the core and the periphery of metropolitan Chicago.

${ }^{4}$ Kiser (1932) has documented the Harlem subculture of natives of St. Helena's Island, South Carolina. Talese (1969) has documented the Chattanooga origins of the New York Times, as well as the Southern subculture in the editorial room: Clifton Daniel, Tom Wicker, Turner Catledge, et al. The authors, descendants of two of the few authentic privates in the Confederate army, yield to no one in local allegiance.

${ }^{5}$ Citation of lexical variants does not imply that phonological and grammatical variants do not exist, as Pederson (1965b) demonstrated for Chicago. 
${ }^{6}$ Linguistic geographers were interested in the education of informants as an indication of exposure to a uniformizing force dealing specifically with language and attitudes towards usage. The informant biographies in Kurath, et al., (1939) and (though abbreviated) in Kurath-McDavid (1961) reveal that only about half of the cultivated (Type III) informants in the Atlantic States even attended college (normal school was not regarded equivalent to college). The fraction is close to half for all the Atlantic states with an appreciable number of informants, including New York, Massachusetts, Connecticut, and Pennsylvania. Community evaluation of family position could more than compensate for non-attendance at a college. Three generations after Henry Ford, the first male Ford will graduate from college in 1973, "After five and a half years of trying... at Boston's easy-going Babson College" (Curtis, 1973).

${ }^{7}$ Data on more remote ancestors was recorded when available. The generalizations about social class are based on the documented profiles of individuals, and the differences among individuals may be examined by interested persons. Unlike Kurath, et al., (1939), recent sociolinguistic studies-Labov (1966). Wolfram (1969), and Fasold (1972)-do not furnish vitae on the informants, but focus on the group.

${ }^{8}$ Field workers consulted a wide range of persons who had a working knowledge of the social values around which their communities organized day-to-day affairs. McDavid (1972) exploited the statewide network of political associations developed by his father in South Carolina.

${ }^{9}$ One fourth of Kurath, et al., (1939) is devoted to regional, state, and local history in New England. Wolfram (1969), Labov (1966), and Fasold (1972) do not provide equivalent information.

${ }^{10}$ Although dialect geographers freely use what sociologists call subjective criteria for assessing social rank, it is apparent that the subjectivity of linguistic geography is not the same as for sociolinguists Shuy, Wolfram, and Riley (1968). Having rank-ordered the numerical scores on the multi-factor scale of social rank they used, Shuy, et al., proceeded to delineate the class structure of Detroit: "The second purpose of the charting is to gain some impressionistic insight as to where 'natural' breaks between scores might occur, thus justifying some breakdown of the social status continuum into discreet "classes'." Linguistic geographers have avoided this sort of subjectivity (1968: 18).

${ }^{11}$ For a comprehensive treatment of the history of dialectology see Pop (1950). A more recent brief historical overview is Viereck (1973). For an interpretive analysis of approaches to several major problems, see Kurath (1972).

${ }^{12}$ The spread of these linguistic boundaries is known as the Rhenish fan. Cartographic representations appear in most works dealing with historical linguistics, e.g., Bloomfield (1933), Lehmann (1962).

${ }^{13}$ Gilliéron did not consider Parisians to be dialect speakers; therefore he did not sample the speech of Paris.

${ }^{14}$ Gumperz (1966), in a sociolinguistic study of Hemnesberget, Norway, took pains to sample the speech of the surrounding territory for variables possibly significant in the town.

${ }^{15}$ Labov (1966: Chapter III) has shown the sociolinguistic stratification among sales clerks in three New York City department stores, Saks Fifth Avenue, Macy's, and S. Klein. Occupational indices of class position, like the Edwards index, run the risk of being too broad, since all clerks would be lumped together.

${ }^{16}$ Metropolitan areas too have their distinctive vocabularies. See Pederson (1964; forthcoming) on Chicago.

${ }^{17}$ Frigidaire parallels the spread of kerosene, once a trade name, at the expense of local terms like coal oil. 
${ }^{18}$ Paddock (1966) shows the existence in Newfoundland of a verb system with features attributed to Black English, but with more regular occurrence. Wright (1905: 296-297) indicates that the tendency to use $-s$ in all persons of the present tense, $I$, you, we, they, as well as he sleeps, was rather general in the northern parts of Great Britain.

${ }^{19}$ Such archives of recordings as those assembled by folklorists at the Memorial University of Newfoundland are an invaluable resource for the student of language. Likewise oral history projects, as Williams (1969), or the Watergate tapes.

${ }^{20}$ Folklorists tell us that the belief that folklore is disappearing is itself folklore (Foster, 1972).

21 Much the same is true with regard to paralanguage, the linguistically non-significant noises that accompany language. The differential between the greatest and least stresses and pitches is greater for Southerners than for Midwesterners. Southerners conclude that Midwesterners speak in a monotone, and Midwesterners believe Southerners talk more slowly than others.

The stylistic versatility that most Southerners take for granted is likely to be disconcerting to those from other regions. The punctilious courtesy which Southern senators extended to witnesses at the Watergate hearings perplexed the same commentators who have been distressed by the cornpone oratory at Southern political gatherings. But the Southern listener recognizes this courtesy as a warning to the witnesses that the truth is expected and that no quarter will be given those who take liberties with it.

${ }^{22}$ Institutionalized misapprehensions are rife. In the underworld a gum moll is not the consort of a gangster, but a female professional pickpocket (Mencken, 1963: 719n).

\section{References}

Allen, Harold B.

1973- Linguistic Atlas of the Upper Midwest. Minneapolis: University of Minnesota.

Atwood, E. Bagby

1953 A Survey of Verb Forms in the Eastern United States. Ann Arbor: University of Michigan Press.

1962 The Regional Vocabulary of Texas. Austin: University of Texas Press.

Bailey, Charles-James N.

1973 "The patterning of language variation." Pp. 156-186 in R.W. Bailey and J.L. Robinson (eds.), Varieties of Present-Day English. New York: McMillan.

Bloomfield, Leonard

1933 Language. New York: Holt.

Bridenbaugh, Carl

1938 Cities in the Wilderness. New York: Ronald.

Brown, Roger

1965 Social Psychology. New York: The Free Press.

Cassidy, Frederic G.

Dictionary of American Regional English (in progress).

Curtis, Charlotte

1973 "Edsel finally succeeds: Fords celebrate first male to graduate from college." The New York Times (September $3)$. 
Dalby, David

1971 "O.K., A.O.K., and O Ke." The New York Times (January 8).

Davis, Allison, Burleigh B. Gardner and Mary R. Gardner 1941 Deep South. Chicago: University of Chicago Press.

Davis, Alva L. and Raven I. McDavid, Jr. 1949 "Shivaree: an example of cultural diffusion." American Speech 24: 49-55.

Davis, Lawrence $M$.

1969 "Dialect research: mythology versus reality." Orbis 18:332-337.

1970 "Social dialectology in America: a critical survey." Journal of English Linguistics 4:46-56.

Davis, Lawrence M. (ed.)

1972 Studies in Linguistics in Honor of Raven I. McDavid, Jr. University of Alabama: University of Alabama Press.

D'Eloia, Sarah G.

1973 "Issues in the analysis of nonstandard Negro English: a review of J.S. Dillard's Black English: Its History and Usage in the United States." Journal of English Linguistics 7: 87-106.

Dieth, Eugen

1948 "Linguistic geography in New England." English Studies 29: 65-78.

Dillard, J. L.

1972 Black English: Its History and Usage in the United States. New York: Random House.

Dollard, John

1937 Caste and Class in a Southern Town. New Haven: Yale University Press.

Fasold, Ralph

1972 Tense Marking in Black English: A Linguistic and Social Analysis. Washington, D.C.: Center for Applied Linguistics.

Foster, Charles W.

1972 "Folklore and the LAGS field worker." Pp. 61-70 in Pederson, et al..

Frank, Yakira H.

1948 "The speech of New York City." Ann Arbor: University of Michigan, unpublished Ph.D. dissertation.

Gallaher, Art, Jr.

1961 Plainville Fifteen Years Later. New York: Columbia University Press.

Gilliéron, Jules

1902-10 Atlas Linguistique de la France. Paris.

Gumperz, John J.

1966 "On the ethnology of linguistic change." In William Bright (ed.), Sociolinguistics: Proceedings of the 1964 UCLA Conference. The Hague: Mouton. 
Hubbell, Alan F.

1950 The Pronunciation of English in New York City: Consonants and Vowels. New York: King's Crown Press.

Jaberg, Karl and Jakob Jud

1928-40 Sprach- und sachatlas Italiens und der Südschweiz. Zofingen.

Key, V. O., Jr.

1949 Southern Polities in State and Nation. New York: Alfred A. Knopf.

Kiser, Clyde Vernon

1932 Sea Island to City: A Study of St. Helena Islanders in Harlem and Other Urban Centers. New York: Columbia University Press.

Kökeritz, Helge

1953 Shakespeare's Pronunciation. New Haven: Yale University Press.

Kurath, Hans

1949 A Word Geography of the Eastern United States. Ann Arbor: Univeristy of Michigan Press.

1968 "The investigation of urban speech." Publications of the American Dialect Society 49:1-7.

1972 Studies in Area Linguistics. Bloomington: Indiana University Press.

Kurath, Hans and Guy S. Lowman, Jr.

1970 "The phonological structure of the dialects of southern England." Publications of the American Dialect Society 54.

Kurath, Hans and Raven I. McDavid, Jr.

1961 The Pronunciation of English in the Atlantic States. Ann Arbor: University of Michigan Press.

Kurath, Hans, et al.

1939 Handbook of the Linguistic Geography of New England. Providence, Rhode Island: American Council of Learned Societies [2nd ed., 1973, New York: AMS Press].

1939-43 Linguistic Atlas of New England. 3 volumes bound as 6. Providence, Rhode Island: American Council of Learned Societies [reprinted 1972, 3 volumes. New York: AMS Press].

Labov, William

1963 "The social motivation of a sound change." Word 19:273-309.

1966 The Social Stratification of English in New York City. Washington, D.C.: Center for Applied Linguistics.

1972 "The recent history of some dialect markers on the island of Martha's Vineyard, Massachusetts." In L.M. Davis (ed.), 1972, 81-121.

Lehmann, Winfred $P$.

1962 Historical Linguistics: An Introduction. New York: Holt, Rinehart and Winston. 
Levine, Lewis and Harry J. Crockett, Jr.

1966 "Speech variation in a Piedmont community: postvocalic r." Pp. 75-98 in Stanley Lieberson (ed.), Explorations in Sociolinguistics, International Journal of American Linguistics 33, No. 4 (part 2).

Lynd, Robert S.

1937 Middletown in Transition. New York: Harcourt, Brace, \& Co.

Lynd, Robert S. and Helen M. Lynd

1929 Middletown: A Study in American Culture. New York: Harcourt, Brace \& Co.

McDavid, Raven I., Jr.

1948 "Post-vocalic /-r/ in South Carolina: a social analysis." American Speech 23:194-203.

1950 "Review of Lorenzo D. Turner, Africanisms in the Gullah Dialect." Language 26:323-333.

1958 "Review of Kökeritz," 1953. Studies in Linguistics 13:46-49.

1967 "Historical, regional, and social variation." Journal of English Linguistics 1: 24-40.

1969 "The language of the city." Midcontinent American Studies 10:48-59.

1970 "The urbanization of American English." Jahrbuch für Amerikastudien 16: 47-59.

1972 "Field procedures: instructions for investigators, Linguistic Atlas of the Gulf States." Pp. 33-60 in Pederson, et al.

McDavid, Virginia G.

1956 "Verb forms in the North Central States and Upper Midwest." Minneapolis: University of Minnesota, unpublished Ph.D. dissertation.

\section{Marckwardt, Albert $\mathrm{H}$.}

1948 "Want with ellipsis of verbs of motion." American Speech 23: 3-9.

Mencken, H. L.

1963 The American Language. [One-volume abridged edition; the 4th edition and two supplements, edited with new material by Raven I. McDavid, Jr., with the assistance of David W. Maurer]. New York: Alfred A. Knopf.

O'Cain, Raymond K.

1972 "A social dialect survey of Charleston, South Carolina." Chicago: University of Chicago, unpublished Ph.D. dissertation.

Paddock, Harold

1966 "The dialect of Carbonear, Newfoundland." Memorial University of Newfoundland, unpublished M.A. thesis.

Pederson, Lee $\mathrm{A}$.

1964 "Terms of abuse for some Chicago social groups." Publications of the American Dialect Society 42:26-48. 
1965a "The pronunciation of English in metropolitan Chicago: consonants and vowels." Publications of the American Dialect Society 44.

1965b"Some structural differences in the speech of Chicago Negroes." Pp. $28-51$ in Roger W. Shuy (ed.), Social Dialects and Language Learning. Champaign, Illinois: National Council of Teachers of English.

1972 "Black speech, white speech and the Al Smith syndrome." Pp. 123-134 in L.M. Davis (ed.), 1972.

Chicago Words: The Urban Vocabulary (forthcoming).

Pederson, Lee A., et al.

1972 A Manual for Dialect Research in the Southern States. Atlanta: Georgia State University [2nd edition, University of Alabama: University of Alabama Press].

Pickford, Glenna Ruth

1956 "American linguistic geography: a sociological appraisal." Word 12: 211-235.

Pop, Sever

1950 La dialectologie: apercu historique et méthodes d'enquètes linguistiques. Gembloux, Belgium.

Read, Allen Walker

1963a "The first stage in the history of O.K.." American Speech 38: 5-27.

1963b"The second stage in the history of O.K.." American Speech 38: 83-102.

Reed, Carroll

1961 "Double dialect geography." Orbis 10:308-19.

Shuy, Roger W., Walter A. Wolfram, and William K. Riley

1968 Field Techniques in an Urban Language Survey. Washington, D.C.: Center for Applied Linguistics.

Talese, Gay

1969 The Kingdom and the Power. Cleveland and New York: World Publishing Company.

Viereck, Wolfgang

1973 "The growth of dialectology." Journal of English Linguistics 7:69-86.

Warner, W. Lloyd

1942 The Status System of a Modern Community. New Haven: Yale University Press.

1949 Social Class in America. Chicago: Science Research Associates.

Warner, W. Lloyd, et al.

1941 The Social Life of a Modern Community. New Haven: Yale University Press.

Williams, T. Harry

1969 Huey Long. New York: Random House. 
Withers, Carl [James West, pseud.]

1945 Plainville, U.S.A. New York: Columbia University Press.

Wrede, Ferdinand

1926-39 Deutscher sprachatlas. Marburg/Lahn.

Wright, Joseph

1898-

1905 English Dialect Dictionary. Oxford.

1905 English Dialect Grammar. Oxford. 